\title{
Why National Culture Should Be at the Heart of Innovation Management Tony Smale
}

\author{
"The belief that human cultures in the workplace") \\ should resemble the laws of physics and engineering \\ is a cultural, not a scientific belief. \\ Fons Trompenaars and Charles Hampden-Turner \\ In Riding the Waves of Culture (1998)
}

\begin{abstract}
Over a period of decades, a substantial body of knowledge has accumulated that correlates national culture and socially and economically important behaviour, including innovation practice. National culture is an interconnected web of mental models that is shared by national groups and transcends the individual. It is highly influential in moderating the cognition and behaviour of groups and individuals. Different resources, including cognition and behaviour, are required at the different stages of the innovation process, and the context, including national culture (within which innovation is practiced), is an important consideration in designing strategy. Because innovation is a psychological and social process, understanding how national culture moderates that cognition and behaviour within the different stages of the innovation process and how the wider innovation ecosystem impacts innovation practice is central to understanding, strategizing and managing the innovation process. However, there has been limited application of this knowledge by practitioners. Therefore, this article examines the importance of national culture from a practitioner perspective, distilling the managerial implications and providing a list of questions that serve as a checklist to enable practitioners to analyze the implications of their own national and organizational context.
\end{abstract}

\section{Introduction}

There is a popular misconception that there is a universal innovation model that can be applied to all strategy and policy without translation across cultures, but "one best way is a yearning not a fact" (Trompenaars \& Hampden-Turner, 1998). This misconception may arise in part from the domination of the academic and especially the popular literature by an American cultural paradigm that is based on an assumption of "maximizing", that is, the pursuit of the best possible outcome given the prevailing constraints which themselves are favourable to this pursuit. This paradigm includes factors such as attitudes to risk and failure (e.g., as reflected in bankruptcy laws), positive attitudes to venture financing, and the pursuit of economic objectives ahead of social ones. It is in contrast to a satisficing paradigm (as exists in New Zealand, for instance) where people settle for a "good enough" outcome and have punitive bankruptcy laws, constrained attitudes to venture finance, and pursue social objectives ahead of economic ones (Crocombe et al., 1991; Morrison \& Conaway, 2006). To counterbalance this misconception, this article argues that the impact of national culture on cognition and behaviour through various channels should be taken account of in the practice of innovation management.

The creation of wealth is, according to NESTA (2007), the only valid measure of innovation performance. However, being creative or inventive is no guarantee of achieving this desired outcome (Baumol, 2004; Freeman, 2002), nor is grouping highly creative people together any guarantee of inventiveness (Trompenaars, 2007). Rather, in this article, it will be established that there are two key stages of the innovation process, that different "resources" including cognition and behaviour are required for each stage, and that different na- 


\section{Why National Culture Should Be at the Heart of Innovation Management} Tony Smale

tions have relative strength or weakness in these two stages, to some statistically significant degree attributable to national culture.

Spolaore and Wacziarg (2010) reported that institutional design is, in part, a function of national culture. Consequently, institutions, processes, policies and the like, as well as cognition and behaviour, in the absence of compensatory strategies and policies, will be designed with a bias towards national culture. The key argument advanced here is that, because some nations and firms naturally favour one or other stage of the innovation process, strategies must be designed accordingly. This article therefore explores the role of national culture in innovation outcomes and argues that there is sufficient evidence to warrant inclusion of national culture considerations in designing innovation strategy and policy. It concludes with a checklist to assist practitioners in incorporating considerations of national culture into their strategizing and management.

\section{National Culture: Definition and Role}

Distinct cultures evolved as different groups adapted to their respective challenges, as they "solved problems and reconciled dilemmas" (Trompenaars \& HampdenTurner, 1998). That is, national culture evolved as a consequence of differences in ancient innovation strategies. Accordingly, the most comprehensive and useful definition of national culture may be: "a learned, socially transmitted set of behavioural standards. It is held, expressed, and shared by individuals through their personal values, norms, activities, attitudes, cognitive processes, interpretation of symbols, feelings, ideas, reactions and morals" (Morris et al., 1994). National culture moderates cognition and behaviour by filtering the data received by the brain and providing mental models and heuristics for the interpretation of what data makes it through the filtering process. Such mental models "are deeply ingrained assumptions, generalizations, or even pictures or images that influence how we understand the world and how we take action" (Senge, 2006).

Ultimately, however, the greatest practical impact of national culture likely comes from the interface between the individuals, groups, and institutions involved in innovation and the wider groups and national environment they function within and the prevailing attitudes to risk, failure, collaboration and sharing of resources, funding, creativity, entrepreneurship, discovery, and adventure. These aspects are all of significance to the innovation process and are all moderated by national culture. This impact can be profound when a cultural fit is absent.

The impact of national culture on how individuals and groups think and behave is substantial and can even influence the development of neural pathways (Zaltman, 2003), a process "which in turn impacts the way the individual approaches problem solving and day-to-day work" (Livermore, 2011). National culture is more influential in how we process data, draw conclusions, and decide upon our actions than age, race, gender, religion, education, or occupation (Livermore, 2011; Trompenaars \& Hampden-Turner, 1998). There is also evidence that, even in science, interpretation of apparently objective data is impacted by national culture (e.g., Fanelli \& Ioannidis, 2013; Hofstede, 1994; Senge, 2006).

As in any complex system, the individual elements do not function in isolation and instead form a complex web that waxes and wanes in its influence depending on context (Trompenaars \& Hampden-Turner, 1998). The challenge for practitioners therefore is to attempt to understand that complex web and its interaction with the contextual environment and then reconcile the strategy and organizational culture design with the conflicts or dilemmas that represents.

\section{National culture and socially and economically import- ant behaviours}

Work by various authors, in particular Hofstede (2001), House and colleagues (2001), Schwartz (1999), and Trompenaars and Hampden-Turner (1998), has established that differences in cognition and behaviour moderated by national culture exist between national groups in material and predictable ways and can be ranked and compared using dimensions such as femininity/masculinity, individualism/collectivism, power distance index, uncertainty avoidance, and universalism/particularism. The works are not without detractors, not the least of which is bitter disagreement between the principle exponents in the field with Hofstede (2001) describing the typologies of Trompenaars and Hampden-Turner or Schwartz as no more than "categories" of culture or "intercorrelated flavours". Although the typologies of the authors listed above vary in the description of their dimensions, they show clearcut differences between, for example, northwest Europe (analysis, logic, systems, and rationality) and the Euro-Latin region (more person related, intuitive, and sensitive) and even between neighbouring Dutch 


\section{Why National Culture Should Be at the Heart of Innovation Management}

\section{Tony Smale}

and Belgians (Trompenaars \& Hampden-Turner, 1998). At the very least, the typologies offer different insights of use to practitioners. For example, Schwartz's affective autonomy provides a useful predictor of a preference for individual adventure, inquiry, and discovery, which might reasonably be associated with initiation.

The published rankings of national culture dimensions (e.g., Hofstede, 2001; House et al., 2001; Schwartz, 1999; Trompenaars \& Hampden-Turner, 1998) are often (but not always) averaged for entire countries, and it is acknowledged that there are significant regional differences, for example, between northern and southern Italy or the east and west coasts of the United States. But, irrespective of these findings, each subset tends to share common biases (Trompenaars \& Hampden-Turner, 1998). Concern is also sometimes expressed about the stability of culture. Some dimensions such as masculinity/femininity do appear to be changing relatively rapidly, but the evidence points to extremely slow overall change in national culture. Hofstede (2001) claims that the values held by a culture in the year 1900 were already evident in 1700 and Trompenaars and Hampden-Turner (1998) make reference to tracing culture to the Roman period. Spolaore and Wacziarg (2012) go further, claiming that the roots of modern European cultures can be traced to the Neolithic period. Nonetheless, if change should occur, it reinforces rather than detracts from the need for practitioners to be fully cognizant of the role and impact of cognition and behaviour moderated by national culture.

\section{Psychological and social processes}

National culture moderates cognition and behaviour is salient because "creativity, innovation, and initiative are psychological [and social] processes" (Rank et al., 2004). That is, national culture is a function of how individuals and groups of people think and behave. Innovation should therefore be analyzed, planned, and managed from a series of perspectives including national culture. There is no suggestion that narrower analyses and conclusions are wrong, but they are incomplete and risk overlooking the complexities of systemic thinking.

\section{Stages of the innovation process}

The literature describes, across different models, as many as 13 stages of the innovation process (INNOCULT, 2006; Nakata \& Sivakumar, 1996). However, one model in particular that adopts two stages - initiation and implementation (INNOCULT, 2006; Marino, 1982; Rank et al., 2004; Scott \& Bruce, 1994; Zmud, 1982) - is particularly salient for this discussion. Initiation is the process of engaging in and supporting new ideas, novelty, experimentation, and creative processes that may result in new products, services, or technological processes (Lumpkin \& Dess, 1996). Implementation is the development, sale, and adoption of those new products, services, and processes to achieve entry into new or existing markets with new or existing products or services with the aim, in this context, of creating new value and wealth/prosperity.

\section{Different "resources" required at different stages}

The literature establishes that different resources, skills, cognition, and behaviours and even "ecosystems" are needed to optimize each of the stages and that progression from one stage to the next is not automatic (e.g., Jaumotte \& Pain, 2005; Pisano \& Teece, 2007; Shane, 1992).

\section{Correlation between innovation and national culture}

Empirical research has established statistically significant correlations and attributed causality between national culture and economic development and innovation:

1. Economic development (e.g., Hull, 2003; Lundvall, 2006; Schuendeln \& Hassan, 2015; Spolaore \& Wacziarg, 2010; Pohlmann, 2005): Spolaore and Wacziarg (2010) report that national culture may be more influential than "institutional arrangements".

2. Innovation, including differentially both initiation and implementation (e.g., Nakata \& Sivakumar, 1996; Rank et al., 2004; Shane, 1992, 1993, 1995). Various authors argue that human dynamics and national culture play a major role in the efficacy of the innovation process (e.g., Frederick \& Chittock, 2006; Hofstede, 2001; Shane, 1992, 1993, 1995), whereas Rank, Pace, and Frese (2004) and Pohlmann (2005) observe that creativity and innovation are culturally moderated responses to environmental stimuli. Furman, Porter, and Stern (2002) note that "innovative capacity" is a product of both the innovation infrastructure and the environment for innovation as well as the strength of linkages between them. Trompenaars (2007) writes at length on the importance of factoring national culture into the management of "creativity and innovation". It is possible therefore to use this information to predict which national groups will have relative strengths in innovation and will provide supportive cultures for the respective stages of the innovation process. 


\section{Why National Culture Should Be at the Heart of Innovation Management}

\section{Tony Smale}

Trompenaars (2007) establishes that the same dimensions and correlations can be used to rank and compare both organizational and national cultures. This approach facilitates ready mapping of the two types of culture for easy visual comparison, or at least an approximation. Figure 1 shows examples of dimensions associated with the two stages of innovation alongside an example of two countries possessing dimensions that predict a preference for initiation (New Zealand) and implementation (Japan) respectively. Organizational culture can be mapped and overlaid on the same grid if desired. The first map was constructed by plotting the reported correlations between national culture dimensions and the two stages of innovation as reported by Covin and Slevin (1991); Lumpkin and Dess (1996); Lee and Peterson (2000); Nakata and Sivakumar (1996); Rank, Pace, and Frece (2004); and Shane $(1992,1993)$.The second map is constructed by mapping those same dimensions for the ratings for the two countries respectively, as reported by Trompenaars and Hampden-Turner (1998), Schwartz (1999), Hofstede (2001), and House, Javadin, and Dorfman (2001).

Of considerable salience to innovation practitioners is Nakata and Sivakumar's (1996) integrative review that clarified the correlations between national culture and initiation and implementation; it showed that the correlations are effectively inverse and mutually exclusive.
That is, cultures are spread across a continuum from a strong preference for the cognition and behaviour associated with initiation - many countries with AngloSaxon roots are at this end of the continuum - through to those with an inclination to the detail and discipline of implementation. Most Asian and Middle Eastern cultures fall into the latter category. This pattern can be referred to as innovation orientation.

\section{Not prisoners to culture}

A key consideration here is that firms and nations are not prisoners of their national culture provided they devise their strategies accordingly. For example, when research by Helmreich and Merrit (1998) established the role of national culture in disastrous safety record of Korean Airlines from the 1970s to the 1990s , new international safety rules to deal with what is now referred to in the airline industry as "gradient" quickly saw the airline become a paragon of aviation safety. In the past, many nations and firms have, apparently by serendipity, developed compensatory innovation strategies. According to Gareth Chaplin, Chief Economist New Zealand Trade and Enterprise (personal communication, 2012), China recently appears to have implemented a more deliberate strategy to complement its existing implementation-biased culture with strategies to augment initiation by investing heavily in research, science, and technology education and institutions, and in acquiring highly inventive foreign businesses.
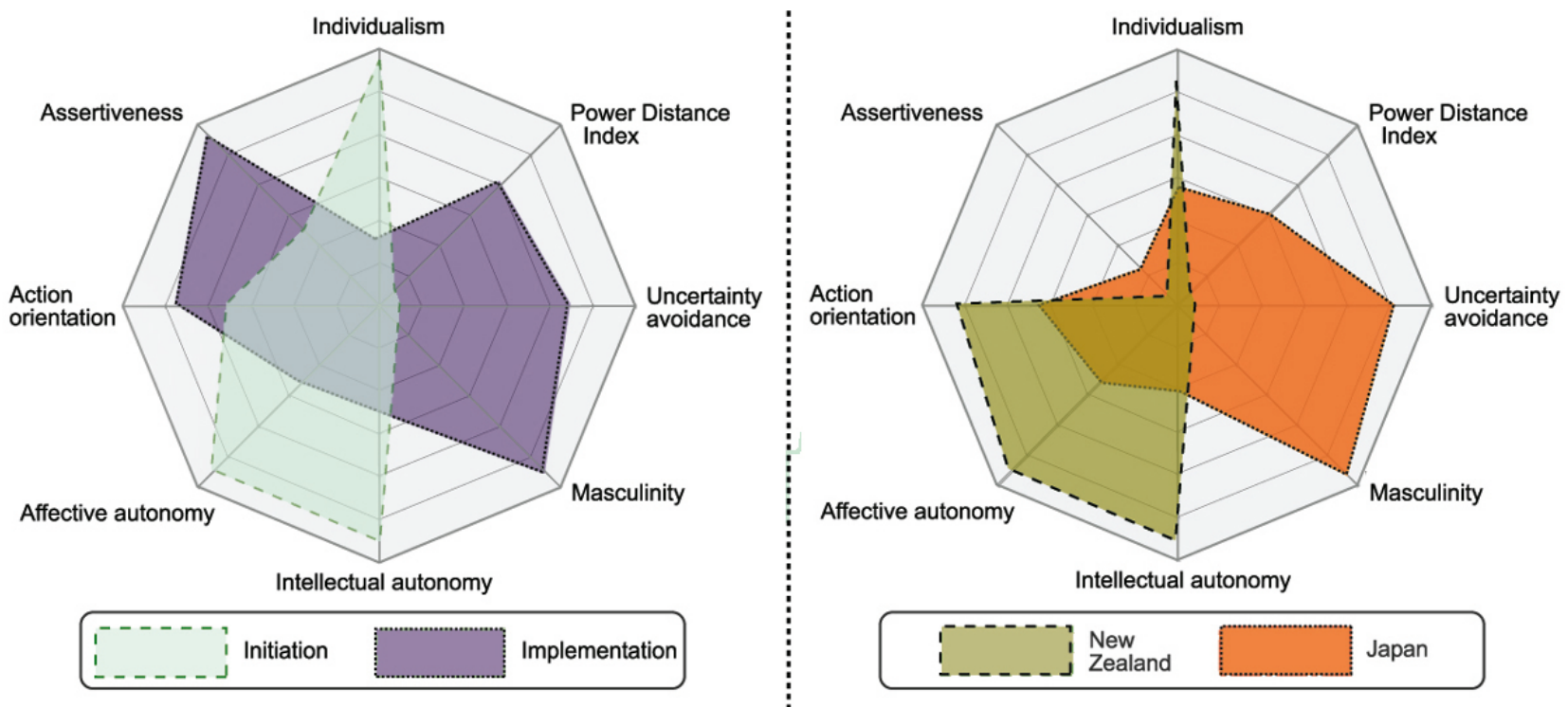

Figure 1. Culture maps showing (left) the comparative "shape" of cultures favouring initiation and implementation respectively and (right) two country examples showing equivalent preferences.

Note: Low assertiveness is not a barrier to initiation although high assertiveness favours implementation. 


\section{Why National Culture Should Be at the Heart of Innovation Management Tony Smale}

\section{How National Culture Impacts the Innova- tion Process}

National culture impacts the innovation process in two principal ways:

1. Although we cannot predict the innovation-related cognition and behaviour of any individual from their national culture, because cultures overlap, we can as a matter of probability conclude the likelihood of them being biased in one direction or the other. We can assume that they will be more comfortable and familiar with environments aligned with their own national culture. Conversely, they are likely to experience some cognitive dissonance when there is neither alignment nor support.

2. Because institutional arrangements, financial systems, attitudes to risk and failure, and so on are all functions of national culture (Spolaore \& Wacziarg, 2010), institutions performing the innovation process are inevitably impacted by that environment. When goals, strategies, organizational culture, and national culture are not coincident, there will be tensions, dissonance, conflict and dilemmas. When they are aligned, the opportunity for synergies is created.

Consider the following example in which national culture is, in the author's experience, a plausible contributor to New Zealand's position in the innovation landscape. New Zealand's national culture comprises an array of cultural dimensions such as high affective autonomy, high individualism, and low uncertainty avoidance that favour the cognition and behaviour associated with initiation. As a result, we can predict that it will have a strong bias towards initiation and that appears in practice to be the case. This bias may explain why i) the country spends less on research, science, and technology than most of the nations that it compares itself with; ii) it publishes science at twice the OECD average; and iii) it patents at one quarter the OECD average (OECD, 2010). New Zealand institutions are examples of high-level initiation not translating into innovation outcomes. The OECD has described this and similar situations as "The New Zealand paradox" (OECD, 2003), because its economic fundamentals, including its forward-facing innovation indicators suggest it should perform much better than it does. For whatever reason, the net effect is that New Zealand does not generate the yield from its creativity that it potentially could. The Ministry of Economic Development (MED, 2007) described this as a "wedge" or "barrier". Drummond (2011), in his paper entitled "Confessions of a Serial Productivity Researcher", makes a similar lament for Canada and the parallels he reports between the two countries are remarkable.

\section{Why Understanding National Culture Is Increasingly Important}

As recently as twenty five years ago, many workplaces, especially those outside of academia, were comparatively culturally homogenous. Everyone looked and sounded familiar. They shared familiar values and similar life goals. Historically, even where firms operated in foreign lands, a head office's cultural paradigm tended to prevail irrespective of where the operation was located (Trompenaars \& Hampden-Turner, 1998). Firms from the Netherlands led and continue to lead in the adoption of national culture into strategizing, not coincidentally as a result of Hofstede and Trompenaars' Dutch roots. The net effect of increasing heterogeneity is not some sort of averaging where the significance of national culture is diluted but is rather the exact opposite. Paradoxically, as Ang, Van Dyne, and Tan (2010) state, "although technology is often a force for convergence, deep-seated cultural differences and cultural diversity present critical challenges to people all over the world. In sum, globalization increases intercultural interactions and also increases the probability of cultural misunderstandings, tensions and conflicts." That is, a greater proportion of the workforce is operating outside of their own national culture context and are managed by and work with people from different cultural backgrounds (Livermore, 2011). Along with rising nationalism (Trompenaars, 2007), this mean that the potential for inter-cultural misunderstandings and resulting performance issues is increasing. Consequently, the need for managers in all disciplines to accommodate within their strategies the variety of national cultures and contexts is heightened.

\section{Implications for Practitioners}

But, in practice, how can organizations reconcile national culture with strategy? Below, we list the implications and associated recommendations for practitioners and then offer a checklist of required information and possible actions:

1. Attempting to directly replicate strategies and policies across different firms and nations, without proper consideration of national culture, carries a considerable risk. Learn from others but do not imitate without cultural translation. 


\section{Why National Culture Should Be at the Heart of Innovation Management}

\section{Tony Smale}

2. Practitioners need to be fully cognizant of the national, organizational, and personal cultural paradigms at play, their relationship with strategy, and the potential conflicts and dilemmas that represents.

3. When strategy, organizational culture, and national culture are reconciled, or at least not in conflict, then synergies are likely. When they are not, friction points arise (recognizing that friction points themselves may give rise to new initiation) and returns may be compromised. Strategy is overwhelmed by culture.

4. Resources are invested in the initiation stage. Value is created and harvested in the implementation phase.

5. In order to create and harvest value, firms and nations must have access to both initiation and implementation.

6. Initiation can be exogenous but the point of value harvest (part of the implementation stage) cannot be.

7. An abundance or surplus of capability and capacity in one stage cannot substitute for a deficit of the other.

8. If a firm or nation has comparative strength in one or other of the innovation stages, further investment in that stage will not deliver optimal returns.

9. Woodhouse (2006) found that moderate levels of both bonding and bridging social capitals produced superior results compared to high levels of one or the other. There are significant parallels between the role of the two types of social capital in economic development and cognition and behaviour associated with the two stages of the innovation process. This is key in developing strategy and policy. Firms and nations must first determine their innovation goals (do they need to foster initiation, implementation, or both?) and reconcile that with their comparative strength in each of the two major innovation stages, including the moderating effect of national culture. If a firm or nation wants an end-to-end innovation process then it must, like China, strategize achieving adequate and balanced levels of both initiation and implementation. If the intended strategy is to use exogenous initiation (open innovation), then culture should be aimed towards implementation. For a part of an organization (a whole organization rarely has this goal) that has the sole goal of generating inven- tions and or discoveries with no responsibility for converting those into and harvesting value, then the culture should be biased towards initiation.

10. Although it is widely accepted that workforce cultural diversity is associated with increased creativity, the findings of Milliken and Martins (1996) support the author's own experience: in the absence of specific management strategies, the beneficial effects are lost due to groups and organizations systematically driving out individuals who are different from the majority, that is, those that do not have a cultural fit.

11. The national culture of team members is therefore important. It provides a pointer as to their innovation comfort zone. It will also provide an indication of how robust managing diversity will need to be.

12. Managers must be fully cognizant of the impacts of national culture on the pursuit of their innovation goals and fully factor consideration into their strategizing.

\section{Checklist for practitioners}

1. Does the national culture of the country that we are operating in have a bias towards initiation or implementation?

2. What are our nation's and firm's relative performance in the two stages of the innovation process?

3. What is the implication of the national culture in which we operate in for funding, risk taking, collaboration, relationships with government, competition, etc.?

4. What are our innovation goals - drive initiation, implementation, or balance both, outsource/in-house initiation?

5. To what degree do our organizational and national cultures align and complement or hinder our goals and strategies?

6. What culture or cultures do we need to promote and which strategies do we need to adopt?

7. Is our organizational culture aligned with the national culture in which we operate? If not, what are the implications for the organization and its staff?

8. Where in the innovation process is the point that value is created and available for harvest? 


\section{Why National Culture Should Be at the Heart of Innovation Management}

\section{Tony Smale}

\section{Do we "own" that point?}

10. What is the diversity of our team? How does this diversity relate to our organizational culture and the national culture in which we operate?

11. How robust does our diversity management need to be to ensure the desired cognition and behaviour are facilitated and cognitive dissonance minimized?

\section{Conclusion}

In designing innovation strategies, managers must be fully cognizant of the different stages of the innovation process; their relative personal, organizational, and national strengths or biases towards those stages; and the implications of organizational and national culture. This awareness will provide insights to the dilemmas and conflicts that they will need to reconcile or resolve and where the opportunities for creating synergies exist. They must, in order to apply the available knowledge connecting national culture and innovation performance, case by case, design strategy that is context specific where goals, institutional culture, staff traits, and national culture are aligned and work in unison. The alternative risks under-performance and suboptimal returns on investment in innovation.

\section{References}

Ang, S., Van Dyne, L., \& Tan, M. L. 2010. Cultural Intelligence. In R. J. Sternberg \& S. B. Kaufman (Eds.), The Cambridge Handbook of Intelligence: 582-602. Cambridge, UK: Cambridge University Press.

Baumol, W. J. 2004. Entrepreneurial Cultures and Countercultures. Academy of Management Learning and Education, 3(1): 316-326. http://dx.doi.org/10.5465/AMLE.2004.14242240

Covin, J. G., \& Slevin, D. P. 1991. A Conceptual Model of Entrepreneurship as Firm Behaviour. Entrepreneurship Theory and Practice, 16(1): 7-25.

Crocombe, G. T., Enright, M. J., \& Porter, M. E. 1991. Upgrading New Zealand's Competitive Advantage. Auckland: Oxford University Press.

Drummond, D. 2011. Confessions of a Serial Productivity Researcher. International Productivity Monitor, 22: 3-10.

Fanelli, D., \& Ioannidis, J. P. A. 2013. US Studies May Overestimate Effect Sizes in Softer Research. In Proceedings of the National Academy of Sciences of the United States of America, 110(37): 15031-15036.

http://dx.doi.org/10.1073/pnas.1302997110

Frederick, H. H., \& Chittock, G. 2006. Global Entrepreneurship Monitor Aotearoa New Zealand: Executive Report. Auckland, NZ: New Zealand Centre for Innovation and Entrepreneurship.

\section{About the Author}

Tony Smale is a Principal Management Consultant with Forté Management, an independent thinking New Zealand business, consulting, coaching, and training practice. Tony began life as a laboratory scientist and manager. He holds an MBA from Henley Business School at the University of Reading, United Kingdom, and is accredited as an Economic Development Professional. Tony's MBA dissertation was entitled The Impact of National Culture on New Zealand's Innovation Outcomes. Since then, he has complemented that work by nearly a decade exposing and testing the arguments in the dissertation with innovation, management, and economic development professionals across many nations and especially working with them to explain and reconcile the dilemmas and conflicts that they encounter in their work and personal lives, both living and working in their home countries and especially as immigrants in foreign cultures. $\mathrm{He}$ is an experienced speaker and has completed a number of international engagements including at the UNFCCC, the OECD LEED Forum, and subsequently serving on an OECD Expert Panel.

Freeman, C. 2002. Continental, National and Sub-National Innovation Systems - Complementarity and Economic Growth. Research Policy, 31(2): 191-211. http://dx.doi.org/10.1016/S0048-7333(01)00136-6

Furman, J. L., Porter, M. E., \& Stern, S. 2001. The Determinants of National Innovative Capacity. Research Policy, 31(6): 899-933. http://dx.doi.org/10.1016/S0048-7333(01)00152-4

Helmreich, R. L., \& Merrit, A. C. 1998. Culture at Work in Aviation and Medicine: National, Organisational and Professional Influences. Farnham, UK: Ashgate Publishing.

Hofstede, G. 1994. Management Scientists are Human. Management Science, 40(1): 4-13.

http://dx.doi.org/10.1287/mnsc.40.1.4

Hofstede, G. 2001. Culture's Consequences: Comparing Values, Behaviors, Institutions and Organizations across Nations (2nd ed.). Thousand Oaks, CA: Sage Publications.

House, R., Javadin, M., \& Dorfman, P. 2001. Project GLOBE: An Introduction. Applied Psychology: An International Review, 50(4): 489-505.

http://dx.doi.org/10.1111/1464-0597.00070

Hull, L. 2003. A Promotion of Enterprise Culture - Theory and Practices Working Paper. Wellington, NZ: Ministry of Economic Development. 


\section{Why National Culture Should Be at the Heart of Innovation Management Tony Smale}

INNOCULT. 2006. Deliverable D5: Literature Review - Analysing National Research Systems. Vienna: Comparative Research in the Social Sciences (ICCR)

Jaumotte, F., \& Pain, N. 2005. Innovation in the Business Sector. OECD Economics Department Working Paper No. 459. Paris: OECD Publishing.

Lee, S. M., \& Peterson, S. J. 2000. Culture, Entrepreneurial Orientation and Global Competitiveness. Journal of World Business, 35(4): 401-416.

http://dx.doi.org/10.1016/S1090-9516(00)00045-6

Livermore, D. 2011. The Cultural Intelligence Difference. New York: AMACOM

Lumpkin, G. T., \& Dess, G. G. 1996. Clarifying the Entrepreneurial Orientation Construct and Linking It to Performance. Academy of Management Review, 21(1): 135-172. http://dx.doi.org/10.5465/AMR.1996.9602161568

Lundvall, B. 2006. Nation States, social Capital and Economic Development - A Systems Approach to Knowledge Creation and Learning. Working Paper No.13. Copenhagen, Denmark: Institute for History, International and Social Studies, Aalborg University.

Marino, K. E. 1982. Structural Correlations of Affirmative Action Compliance. Journal of Management, 8(1): 75-93. http://dx.doi.org/10.1177/014920638200800105

MED. 2007. Growth Through Innovation - Sustainable Economic Growth for All New Zealanders. Wellington, NZ: Ministry of Economic Development (MED), New Zealand Government.

Milliken, F. J., \& Martins, L. L. 1996. Searching for Common Threads: Understanding the Multiple Effects of Diversity in Organizational Groups. Academy of Management Review, 21(2): 402-433. http://dx.doi.org/10.5465/AMR.1996.9605060217

Morris, M. H., Davis, D. L., \& Allen, J. W. 1994. Fostering Corporate Entrepreneurship: Cross-Cultural Comparisons of the Importance of Individualism versus Collectivism. Journal of International Business Studies, 25(1): 65-89. http://dx.doi.org/10.1057/palgrave.jibs.8490849

Morrison, T., \& Conaway, W. A. 2006. Kiss, Bow, or Shake Hands (2nd ed.). Avon, MA: Adams Media.

Nakata, C., \& Sivakumar, K. 1996. National Culture and New Product Development: An Integrative Review. Journal of Marketing, 60(1): $61-72$.

http://dx.doi.org/10.2307/1251888

NESTA. 2007. Hidden Innovation: How Innovation Happens in Six 'Low Innovation' Sectors. London: National Endowment for Science, Technology, Arts (NESTA).

OECD. 2003. Economic Surveys: New Zealand. Paris: OECD.

OECD. 2010. Science, Technology and Industry Outlook. Paris: OECD.

Pisano, G. P., \& Teece, D. J. 2007. How to Capture Value from Innovation: Shaping Intellectual Property and Industry Architecture. California Management Review, 50(1): 278-296. http://dx.doi.org/10.2307/41166428
Pohlman, M. 2005. The Evolution of Innovation: Cultural Backgrounds and the Use of Innovation Models. Technology Analysis \& Strategic Management, 17(1): 9-19. http://dx.doi.org/10.1080/09537320500044396

Rank, J., Pace, V. L., \& Frese, M. 2004. Three Avenues for Future Research on Creativity, Innovation, and Initiative. Applied Psychology: An International Review, 53(4): 518-528. http://dx.doi.org/10.1111/j.1464-0597.2004.00185.x

Schuendeln, N., \& Hassan, P. A. 2015. Natural Experiments in MacroEconomics. National Bureau of Economic Research Working Paper 21228. Cambridge, MA: National Bureau of Economic Research.

Schwartz, S. H. 1999. A Theory of Cultural Values and Some Implications for Work. Applied Psychology: An International Review, 48(1): 23-47. http://dx.doi.org/10.1111/j.1464-0597.1999.tb00047.x

Scott, S. G., \& Bruce, R. A. 1994. Determinants of Innovative Behaviour: A Path Model of Individual Innovation in the Workplace. Academy of Management Journal, 37(3): 580-607. http://dx.doi.org/10.2307/256701

Senge, P. 2006. The Fifth Discipline - The Art \& Practice of the Learning Organisation. London: Random House Business Books.

Shane, S. A. 1992. Why Do Some Societies Invent More than Others? Journal of Business Venturing, 7(1): 29-46. http://dx.doi.org/10.1016/0883-9026(92)90033-N

Shane, S. A. 1993. Cultural Influences on National Rates of Innovation. Journal of Business Venturing, 8(1): 59-73. http://dx.doi.org/10.1016/0883-9026(93)90011-S

Shane, S. A. 1995. Uncertainty Avoidance and the Preference for Innovation Championing Roles. Journal of International Business Studies, 26(1): 47-68.

http://dx.doi.org/10.1057/palgrave.jibs.8490165

Spolaore, E., \& Wacziarg, R. 2012. How Deep are the Roots of Economic Development? National Bureau of Economic Research Working Paper 18130. Cambridge, MA: National Bureau of Economic Research.

Trompenaars, F., \& Hampden-Turner, C. 1998. Riding the Waves of Culture. New York: McGaw-Hill.

Trompenaars, F. 2007. Riding the Whirlwind: Connecting People and Organisations in a Culture of Innovation. Oxford, UK: The Infinite Ideas Company.

Woodhouse, A. 2006. Social Capital and Economic Development in Regional Australia: A Case Study. Journal of Rural Studies, 22(1): 83-94. http://dx.doi.org/10.1016/j.jrurstud.2005.07.003

Zaltman, G. 2003. How Customers Think. Boston, MA: Harvard Business School Publishing.

Zmud, R. W. 1982. Diffusion of Modern Software Practices: Influence of Centralization and Formalization. Management Science, 28(12): 1421-1431. http://dx.doi.org/10.1287/mnsc.28.12.1421 